\title{
PENGEMBANGAN MODEL KEWIRAUSAHAAN SMK MELALUI KOPERASI SEKOLAH
}

\author{
IIN NURBUDIYANI \\ Fakultas Keguruan dan Ilmu Pendidikan Universitas Muhammadiyah Palangkaraya
}

\begin{abstract}
ABSTRAK
Kewirausahaan memiliki peranan penting dalam suatu bangsa. Siswa semestinya dibekali dengan kemampuan akademik dan keterampilan seperti yang terkandung dalam nilai-nilai kewirausahaan untuk menghadapi tantangan masa depan. Oleh karena itu, SMK sangat strategis dalam mengembangkan model pembelajaran kewirausahaan. Tujuan penelitian adalah untuk mengetahui bagaimana kondisi koperasi SMK, model pembelajaran yang digunakan untuk meningkatkan sikap kewirausahaan siswa SMK. Penelitian menggunakan metode penelitian dan pengembangan. Data yang digunakan berupa data kuantitatif, seperti komentar, saran, kritik dari para ahli materi dan pendidikan sebagai rekomendasi untuk pengembangan produk. Data dikumpulkan menggunakan instrumen yang berbentuk tes, observasi, interview dan angket. Data dianalisis dengan menggunakan tehnik path analisis.
\end{abstract}

Kata kunci: pengembangan, kewirausahaan, koperasi sekolah, SMK.

The Development of Entrepreneurship Model for the Vocational School on the Base of School Cooperative.

\section{ABSTRACT}

Entrepreneurship has important roles to play in a nation. Student should be equipped with academic capabilities and practical skills as well as entrepreneurial values and attitudes for future challenges of life. Therefore, a vocational education is strategic to develop through an entrepreneurship model. Purposes of this study are to find out the conditions of school cooperative, models applied to develop learning process for enhancing entrepreneurial attitudes among students, and whether or not the development of learning on the base of school cooperative can enhance the entrepreneurial attitudes among the students of Vocational Schools. The study is conducted by using a research and development method. Data used are quantitative data, such as the assessment scores of attitude tests. The data are supported by qualitative data, such as comment, critique, and recommendation for improvement from material and education experts, of product development. The data are collected using instruments of attitude test, observation, interview and questionnaires. The collected data are analyzed by using a path analysis technique.

Keywords: development, entrepreneurship, school cooperative, vocational school.

\section{PENDAHULUAN}

Krisis moneter di Indonesia pada tahun 1997, mengakibatkan penurunan daya beli masyarakat, kebangkrutan sebagian dunia usaha, serta meningkatnya jumlah PHK, sehingga semakin menambah jumlah pengangguran. Dengan terjadinya krisis moneter juga mengakibatkan semakin sulitnya seseorang untuk mendapatkan pekerjaan. Pandangan yang benar adalah bekerja berarti menciptakan pekerjaan, baik untuk diri sendiri maupun untuk orang lain. Untuk dapat menciptakan pekerjaan dibutuhkan orang yang mempunyai jiwa kewirausahaan. Untuk menjadi seorang wirausahawan diperlukan kemampuan tertentu yang tidak hanya diperoleh melalui pendidikan formal atau non formal, tetapi juga harus didukung adanya jiwa wirausaha yang dapat dilihat dari sikap kewirausahaan. Dengan kata lain, persiapan manusia wirausaha terletak pada penempaan semua daya kekuatan pribadi manusia itu untuk menjadi dinamis dan kreatif, disamping berusaha untuk hidup maju dan berprestasi. Salah satu ciri manusia wirausaha adalah memiliki kepripadian yang kuat, yaitu moral yang tinggi, kepekaan terhadap lingkungan, dan memiliki keterampilan wirausaha. 
Dalam kenyataan ada guru yang statis, kurang terbuka terhadap inovasi, kurang peka terhadap kenyataan dan tantangan hidup, serta kurang tumbuh dalam jabatan mereka, semua ini menghambat guru dalam usaha mendidik siswa menjadi manusia wirausaha. Pembelajaran kewirausahaan di sekolah membutuhkan guruguru yang dapat mengajarkan disiplin ilmu tersebut dengan baik dan benar. Sebagian sekolah telah mendirikan koperasi sekolah tetapi dengan kegiatan yang belum baik, walaupun sudah ada sebagian sekolah yang sudah memiliki koperasi sekolah dengan penyelenggaraan yang baik. Dengan kondisi tersebut menunjukkan bahwa sikap kewirausahaan dikalangan siswa masih belum terbina dengan baik. Untuk itu koperasi sekolah sebagai salah satu wahan bagi siswa dalam menempa diri, untuk memiliki dan menumbuhkan sikap wirausaha menjadi sangat penting keberadaanya.

\section{ISI POKOK KAJIAN}

\section{Kewirausahaan}

Dahulu kewirausahaan dianggap hanya bisa dilakukan oleh orang-orang yang mempunyai banyak duit dan merupakan keturunan dari orang tuannya sebagai pengusaha, namun sekarang kewirausahaan sudah dapat dipelajari oleh siapa saja yang menginginkannya tanpa melihat siapa, dari mana, dan punya apa. Karena kewirausahaan banyak terkait dengan jiwa atau sikap, tetapi harus diingat bahwa jiwa atau sikap juga terkait dengan pemahaman. Banyak bukti menunjukkan hal itu. Misal orang yang berasal dari keluarga wirausahawan seringkali lebih pandai dalam berwirausaha, karena sejak kecil berada dalam lingkungan wirausaha, sehingga secara langsung maupun tidak langsung sudah belajar tentang seluk beluk berwirausaha. Jadi faktor belajar tetap kuat dalam membentuk kemampuan berwirausaha. Hal yang sama juga dikemukakan oleh Irmawati (2003: 45), bahwa kemampuan mengembangkan wirausaha sangat ditentukan oleh kecakapan dari pengelola usaha tersebut. Artinya tingkat pendidikan dan pengalaman berpengaruh terhadap pengembangan usaha disamping modal dan motivasi kerja. Hal ini diperkuat pendapat dari Surya Dharma (2009: 102), bahwa pengembangan kewirausahaan sekolah merupakan trend baru yang mendukung pengembangan suatu pendidikan di berbagai tingkatan.

Hisrich dan Peters (1998: 9), pengertian entrepreneurship sebagai berikut:

Entrepreneurship is the process of creating something new with value by devoting the necessary time and effort, assuming the accompanying financial, physic and social risks and receiving the resulting reward of monetary and personal satisfaction and independence.

Berarti bahwa kewirausahaan adalah merupakan suatu proses mengkreasi sesuatu yang baru yang mempunyai nilai, dengan mencurahkan waktu dan upaya, serta berani menanggung resiko untuk mencapai keberhasilan. Menurut Thomas W. Zimmerer (2005: 16), "Kewirausahaan adalah hasil dari suatu disilpin serta proses sistematis penerapan kreativitas dan inovasi dalam memenuhi kebutuhan dan peluang di pasar." Namun dalam perkembangannya ilmu kewirausahaan mengalami perkembangan sangat cepat dalam berbagai bidang, seperti: niaga, pendidikan, industri, kesehatan dll. Kuratko \& 
Hoodgets (2004: 30), mendefinisikan entrepreneurship sebagai:

Entrepreneurship is a dynamic process of vision, change, and creation. It requires an application of energy and passion toward the creation and implementation of new ideas and creative solution. Essential ingredients include the willingness to take calculated risk-in terms on time, equity, or career, the ability to formulate an effective venture team, the creative skill to marshal needed resources, the fundamental skill of building a solid business plan, and finally, the vision to recognize opportunity where others see chaos, contradiction and confusion.

Berarti bahwa, seorang wirausahawan dalam melakukan aktivitas manajemen strategic dalam keputusan mempertimbangkan kekuatan dan kelemahan wirausaha (internal), juga peluang dan hambatan yang ada dalam lingkungan usaha (eksternal), bermanfaat untuk individu dan masyarakat. Depdiknas (1998: 156), mengartikan entrepreneurship adalah sikap dan perilaku dalam memimpin dan mengelola suatu organisasi/sekolah dengan selalu mencari dan menerapkan cara kerja dan teknologi baru sehingga dicapai efektivitas dan efisien yang tinggi. Dari beberapa definisi diatas dapat kami simpulkan bahwa kewirausahaan adalah ilmu yang mempelajari tentang nilai, kemampuan, sikap dan perilaku seseorang dalam memenuhi tantangan dalam kehidupannya secara efektif dan efisien sehingga ia mampu mandiri dan dapat mengembangkannya kearah yang lebih baik, sehingga efektif dan efisien.

Seorang wirausaha haruslah orang yang mampu melihat kedepan, berfikir penuh perhitungan, mencari pilihan dari berbagai alternatif masalah dan dapat mengambil keputusan dengan tepat dan cepat. Menurut B. N. Marbun (Buchori Alma, 2000: 39), seorang wirausaha harus memiliki ciri-ciri: (1) percaya diri, ditandai dengan watak keteguhan, ketidak ketergantungan, kepribadian mantap dan optimisme; (2) berorientasi tugas dan hasil, ditandai dengan haus akan prestasi, berorientasi hasil, tekun dan tabah, tekad, kerja keras, motivasi, energik dan penuh inisiatif; (3) mengambil resiko, ditandai dengan mampu mengambil resiko, suka pada tantangan; (4) kepemimpinan, ditandai dengan mampu memimpin, dapat bergaul dengan orang lain, menanggapi saran dan kritik; (5) keorisinilan, ditandai dengan inovatif, kreatif, fleksibel, banyak sumber, serba bisa, mengetahui banyak; (6) berorientasi kemasa depan, ditandai dengan pandangan kedepan, perspektif.

Sementara Salim Siagian (Sukidjo, 1998: 104), berpendapat bahwa kualifikasi bagi pengusaha yang baik dan handal adalah sebagai berikut: (1) Memiliki rasa percaya diri dan sikap mandiri yang tinggi; (2) Mau, mampu mencari dan menangkap peluang usaha yang menguntungkan; (3) Mau, mampu bekerja keras dan tekun menghasilkan barang \& jasa serta mencoba cara kerja yang lebih tepat dan efisien; (4) Mau dan mampu berkomunikasi, tawar-menawar, dan musyawarah dengan berbagai pihak yang jujur, hemat dan disiplin; (5) Mencintai kegiatan usahanya secara lugas dan tangguh tetapi cukup luwes; (6) Mau dan mampu meningkatkan kapasitas diri sendiri, perusahaan dengan mamanfaatkan dan memotivasi orang lain; (7) Berusaha mengenal dan mengendalikan lingkungan, menggalang kerjasama yang menguntungkan dengan berbagai pihak. Batasan ciri-ciri kewirausahaan ini menggariskan bahwa untuk bisa menjadi seorang wirausaha diperlukan 
berbagai faktor, diantaranya modal, sumber daya, kreativitas \& kepribadian.

Setiap individu dibekali dengan benih jiwa kewirausahaan, karena secara individu minimal seseorang harus berusaha untuk diri sendiri, kemudian berkembang untuk keluarganya, dan seterusnya dapat berkembang lebih luas lagi untuk orang lain. Besarnya benih kewirausahaan untuk setiap orang berbeda-beda, karena prinsip perbedaan individu. Namun benih akan tetap merupakan benih jika tidak diusahakan untuk tumbuh dan berkembang. Benih akan tumbuh dan berkembang baik jika diberikan perawatan dan lingkungan yang baik, melalui pendidikan dan pelatihan kewirausahaan, sehingga akan menumbuhkan kepribadian wirausaha, kemampuan, dan motivasi untuk berwirausaha (McClelland dalam Suwardie, 2007: 59).

Kewirausahaan adalah disiplin ilmu yang dapat dipelajari (Hisrich \& Peters, 1989: 14), mengatakan "entrepreneurship are not only bornthey develop", yaitu bahwa kewirausahaan bukan bakat bawaan sejak lahir tetapi juga dapat berkembang. Seseorang yang memiliki bakat kewirausahaan dapat mengembangkan bakatnya melalui pendidikan (entrepreneurship are not only born but also made). Dari uraian diatas maka pembelajaran kewirausahaan sangat penting menceritakan atau memberi contoh tentang sosok pengusaha yang sukses dan yang gagal, sehingga dapat memberi wawasan dan gambaran dalam mempersiapkan diri para siswa untuk memilih kerja di kemudian hari.

\section{Sikap}

Pengertian sikap menurut Robbin (2001: 68), adalah sebagai berikut:
Attitude are evaluative statements-either favorable or unfavorable-concerning objects, people, or events. Attitude are not the same as value, but the tho are interrelated. You can see by looking at the three components af an attitude: cognition, affect, and behavior.

Yang berarti bahwa sikap merupakan pernyataan penilaian mengenai sesuatu objek, orang atau peristiwa yang bernilai baik atau buruk. Struktur sikap terdiri dari tiga komponen, yaitu: kognitif, afektif dan psikomotor. Sikap dibangun melalui model ABC (Affect, Behavioral change and Cognition), yaitu:

Attitude develop on the $A B C$ model (affect, behavioral change and cognition). The affective response is psiological response that expresses an individual's preference for an entity. The behavioral intention is a verbal indication of the intention of an individual. The cognitive response is a cocnitive evaluation of the entity to form an attitude.

en.wikipedia.org/wiki/Attitude_(psikology)).

Yang berarti sikap dibangun dari $A B C$ model (afektif, perubahan tingkah laku,dan kognitif). Respon afektif adalah respon psikologi yang menandakan pilihan individu secara terintegrasi. Peri laku adalah indikasi verbal dari intensi individu . Respon kognitif adalah evaluasi kognitif dari isi untuk membentuk sikap. Model $A B C$ ini diperkuat oleh pendapat dari Read Bain (2001), (http: www.brocku. ca/MeadProject/

Bain-1928.html) ia menyatakan bahwa: "Attitude is often used as a synonym for habit. This is usually complicated to some hipothethical instinctive, mental, emotional, or feeling concomitant, latent, inhibited, or active in response". Artinya sikap sering digunakan sebagai sinonim kebiasaan. Sikap biasanya dilengkapi dengan beberapa insting, hopotetikal, mental, emosi atau perasaan, laten, pembiasaan, atau aktif pada respon. Dengan demikian sikap 
dapat dipelajari, dan seseorang bersikap karena mengalami proses belajar. Pengubahan sikap dapat dilakukan secara langsung maupun tidak langsung. Dari uraian diatas dapat disimpulkan bahwa sikap kewirausahaan siswa dapat dilihat dari bagaimana penghayatan siswa terhadap kewirausahaan sampai dengan kemauan siswa untuk bertindak dan mengubah sikap sesuai dengan ciri-ciri kewirausahaan tersebut.

\section{Koperasi}

Menurut Arifin Chaniago (1982: 1), koperasi adalah suatu perkumpulan yang beranggotakan orang-orang atau badan-badan, yang memberikan kebebasan masuk dan keluar sebagai anggota, dengan bekerja sama secara kekeluargaan menjalankan usaha, untuk mempertinggi kesejahteraan para anggotanya. Pengertian koperasi yang senada dikemukakan oleh Margono Djojohadikoesoemo (Hendrojogi, 1999: 21), menyatakan bahwa koperasi ialah perkumpulan manusia seorang-seorang yang dengan sukanya sendiri hendak bekerja sama untuk memajukan ekonomi. Definisi lain menyatakan bahwa koperasi adalah badan usaha yang beranggotakan orang-orang atau badan hukum kopersi dengan melandaskan kegiatannya berdasarkan prinsip koperasi sekaligus sebagai gerakan ekonomi rakyat berdasarkan atas kekeluargaan

(http://id.wikipedia.org/wikipedia.org/wiki/koperasi)

. Berdasarkan pengertian tersebut yang menjadi anggota koperasi adalah: (1) perorangan, yaitu orang yang secara sukarela menjadi anggota koperasi, dan (2) badan hukum koperasi, yaitu suatu koperasi yang menjadi anggota koperasi yang memiliki lingkup lebih luas. Pada masa orde baru kegiatan koperasi di Indonesia mengacu pada Undang-undang Koperasi No. 12 tahun 1967, yang menyatakan bahwa Koperasi Indonesia adalah organisasi ekonomi rakyat yang berwatak sosial, beranggotakan orang-orang atau badan-badan hukum yang merupakan tata susunan ekonomi sebagai usaha bersama berdasarkan atas asas kekeluargaan. Sedangkan Undang-undang No. 25 tahun 1992 tentang Perkoperasian, menyebutkan bahwa koperasi adalah badan usaha yang beranggotakan orangorang atau badan hukum dengan melandaskan kegiatannya berdasarkan prinsip koperasi sekaligus sebagai gerakan ekonomi rakyat yang berdasar atas azas kekeluargaan. Dalam berwiraswasta ada beberapa tata cara atau aturan yang harus kita ikuti, dimulai dari cara pendiriannya, tata tertib, keanggotaanya, bentuk usaha maupun pembagian hasil usahanya.

\section{Koperasi Sekolah}

Koperasi sekolah adalah koperasi yang didirikan di lingkungan sekolah yang anggotaanggotanya terdiri atas siswa sekolah. Koperasi sekolah dapat didirikan pada berbagai tingkatan sesuai jenjang pendidikan, misalnya koperasi SD, koperasi SMP dan seterusnya (http://id.wikipedia.org/wiki/Koperasi-sekolah).

Koperasi sekolah didirikan dalam rangka menanamkan pendidikan koperasi kepada siswa agar tujuan pengembangan koperasi di Indonesia dapat terwujud. Landasan didirikannya koperasi sekolah adalah keputusan bersama antara Departemen Transmigrasi dan Koperasi dengan Pendidikan dan Kebudayaan tanggal 16 Juli tahun 1972 Nomor 275/SKPTS/Mentranskop dan Nomor 0102/U/1983. Surat Keputusan Menteri Tenaga Kerja, Transmigrasi dan Koperasi Nomor 633/SKPTS/Men/1974, menjelaskan bahwa 
koperasi sekolah adalah koperasi yang didirikan di sekolah-sekolah SD, SMP, SMA, Madrasah dan

pesantren

\section{(http://id.wikipedia.org/wiki/Koperasi-sekolah).}

Ciri-ciri koperasi sekolah adalah: (1) koperasi sekolah didirikan dalam rangka kegiatan belajar mengajar para siswa; (2) anggotanya adalah kalangan siswa sekolah yang bersangkutan; (3) tidak disyaratka berbadan hukum; (4) berfungsi sebagai laboratorium pengajaran koperasi di sekolah.

Menurut SK bersama Departemen Transmigrasi dan Koperasi dengan Departemen Pendidikan dan Kebudayaan, tujuan pembentukan koperasi sekolah adalah: (1) Mendidik, menanamkan, dan memelihara suatu kesadaran hidup bergotong royong dan setia kawan serta jiwa demokratis diantara para siswa; (2) Memupuk dan mendorong tumbuhnya kesadaran serta semangat koperasi dikalangan para siswa; (3) Meningkatkan pengetahuan dan keterampilan koperasi dikalangan anggota yang berguna bagi para siswa untuk bekal terjun dimasyarakat; (4) Menunjang program pembangunan pemerintah di sektor perkoperasian melalui program pendidikan sekolah; (5) Membantu dan melayani pemenuhan kebutuhan ekonomi para siswa melalui pengembangan pembagian kegiatan usaha.

\section{Hakekat Pembelajaran di Sekolah Menengah Kejuruan (SMK)}

Menurut Thorndike (Suciati 2001: 3), belajar adalah proses interaksi antara stimulus (yang mungkin berupa pikiran, perasaan atau gerakan). Jelasnya perubahan tingkah laku itu bisa berupa sesuatu yang kongkrit (dapat diamati) atau yang non kongkrit (tidak bisa diamati).
Sedangkan menurut Klein (2000: 2),"Learning can be defines as an experemential process resulting in a relatively permanent change in behavior that cannot be explained by temporary states, maturation, or innate response tendencies". Artinya belajar dapat didefinisikan sebagai hasil proses eksperimental dalam perubahan tingkah laku yang relative permanent yang tidak dapat diucapkan dengan pernyataan sesaat. Waston (Suciati, 2001: 4), mengatakan bahwa belajar adalah proeses interaksi antara stimulus dan respon, namun stimulus dan respon yang dimaksud harus berbentuk tingkah laku yang dapat diamati dan dapat diukur. Sedangkan menurut Skinner (Dimyati, 2002: 9), belajar adalah suatu perilaku. Pada saat orang belajar, maka responnya menjadi lebih baik. Skinner menyatakan bahwa belajar ialah perubahan tingkah laku. Pada saat orang belajar, reesponnya meningkat dan apabila terjadi hal sebaliknya (unlearning), angka responnya menurun. Dari berbagai pandangan para ahli yang mencoba memberikan definisi belajar dapat diambil kesimpulan bahwa belajar selalu melibatkan tiga hal pokok yaitu: adanya perubahan tingkah laku, sifat perubahannya relatif permanen serta perubahan tersebut disebabkan oleh interaksi dengan lingkungan, bukan oleh proses kedewasaan ataupu perubahan-perubahan kondisi fisik yang sifatnya sementara.

Media berasal dari kata medium yang secara harafiah berarti perantara atau pengantar pesan dari pengirim pesan ke penerima pesan (Arief S. Sadiman dkk, 2007: 6). Dalam bahasa arab media adalah perantara atau pengantar pesan dari pengirim pesan kepada penerima pesan (Azhar Arsyad, 2007: 3). Media merupakan 
sebuah komunikasi yang melibatkan antar sumber dan penerima. Dalam suatu proses pembelajaran, ada dua unsur yang sangat penting, yaitu metode pengajaran dan media pembelajaran. Media berfungsi untuk tujuan instruksi di mana informasi yang terdapat dalam media harus melibatkan siswa dalam benak atau mental maupun dalam bentuk yang nyata sehingga pembelajaran dapat terjadi. Dengan adanya media pembelajaran yang berfariasi, diharapkan dapat menumbuhkan minat dan motivasi belajar siswa. Dari beberapa pengertian yang telah dikemukakan diatas dapat dinyatakan bahwa media merupakan bentuk peralatan yang berfungsi merangsang pemikiran, pengantar pesan kepada sasaran dan dapat membangkitkan perasaan.

\section{PEMBAHASAN}

Penelitian ini nantinya dilakukan dengan menggunakan metode penelitian dan pengembangan. Data yang digunakan adalah data kualitatif, seperti skor penialain dari tes sikap. Data ini didukung dengan data kulitatif, seperti komentar, kritikan, dan saran bagi perbaikan dari ahli materi dan pakar pendidikan, serta dari siswa dalam uji coba pengembangan produk tersebut. Semua data ini diperoleh menggunakan instrumen tes sikap, daftar periksa observasi, wawancara, dan kuesionaer. Data yang terkumpul dianalisis menggunakan teknik analisis jalur.

\section{KESIMPULAN}

Sekolah Menengah Kejuruan (SMK) merupakan salah satu lembaga pendidikan formal yang bertujuan untuk menghasilkan tenaga kerja tingkat menengah. Sekolah Menengah Kejuruan sebagai sub sistem pendidikan Nasional mempunyai peluang yang cukup besar untuk ikut serta dalam pembangunan sistem perekonomian yang bertumpu kepada kekuatan rakyat yang tetap tumbuh dalam situasi yang sulit, apalagi jika ditopang oleh pelaku-pelaku bisnis yang kreatif, inovatif dan mempunyai daya tahan terhadap perubahan. Oleh sebab itu SMK perlu melakukan upaya yang mampu menumbuhkan budaya, menciptakan peluang dan memanfaatkan situasi yang ada secara lebih kreatif. Dengan menanamkan nilai-nilai dan norma-norma kewirausahaan kepada siswa, maka diharapkan siswa memiliki jiwa entrepreneur, menumbuhkan wacana baru dalam mengembangkan paradigma perencanaan masa depan yang tidak hanya mengharapkan kesempatan bekerja disektor formal dan informal, tetapi berani menjadi pencipta lapangan kerja. Pendidikan juga harus menghasilkan tenaga-tenaga profesional yang memiliki kemampuan kewirausahaan yang menjadi salah satu pilar utama aktivitas perekonomian nasional.

Kurangnya sikap kewirausahaan yang dimilki siswa dilatar belakangi oleh beberapa faktor. Diantara sekian banyak faktor, faktor yang paling dominan adalah tidak adanya koperasi sekolah atau kurang dimanfaatkannya koperasi sekolah sebagaimana mestinya. Hal ini akan mengakibatkan guru dalam menyampaikan materi pembelajaran khususnya aspek perkoperasian dan kewirausahaan kurang dapat mendesain pembelajaran yang dapat mengarah pada pencapaian tujuan, yaitu peningkatan sikap kewirausahaan siswa. Mengingat pentingnya pembelajaran koperasi dalam meningkatkan sikap kewirausahaan siswa, maka semestinya guru mampu menciptakan pembelajaran koperasi yang dapat menyentuh aspek tersebut. Salah satu 
alternatif yang dapat dipilih untuk dapat meningkatkan sikap kewirausahaan siswa adalah melalui kegiatan koperasi sekolah. Dengan memanfaatkan koperasi sekolah diharapkan dapat memberikan bekal pada diri siswa tentang bagaimana cara berwirausaha.

\section{DAFTAR PUSTAKA}

Alma, Buchori. (2000). Kewirausahaan. Bandung: Alfabeta.

Arifin Chaniago. (1982). Perkoperasian Indonesia. Bandung: Angkasa.

Depdiknas. (2010). Rencana Strategis Departemen Pendidikan Nasional tahun 2010-2914: Menuju Pembangunan Pendidikan Nasional Jangka Panjang 2025. Jakarta: Departemen Pendidikan Nasional.

Hisrich, D. Robert \& Peter, P. Michael. (2002). Entrepreneurship. Fifth Edition, North America: Mc Graw-Hill. Internatonal Edition.

Irmawita. (2003). Analisa Pengembangan Wirausaha melalui Pendidikan Kewirausahaan Pada Industri Kecil Di Kabupaten Tanah Datar. Jurnal IImiah. VISI Nomor 14/THXI/2003.

Koperasi Sekolah. Diakses tanggal 8 Januari 2008 pukul 12.00 dari (http://id.wikipedia.org/wiki/KoperasiSekolah).

Attitude (psychology). Diakses tgl 24 Desember 2007 pukul 15 Wib dari (http://id.wikipedia.org/wiki/attitudepsychology).

Kuratko, Donald \& Hodgetts, Richard. (2004). Enterpreneurship: theory, process and practice, 6 rd Edition. Thomson SouthWestern, Canada.

Suciati dan Prasetya Irawan. (2001). Teori Belajar dan Motivasi. Jakarta: Departemen Pendidikan Nasional.
Undang-undang. (1992). Undang-undang Nomor. 25 Tahun 1992. Tentang Perkoperasian.

Zimmerer, Thomas W \& Scarborouh, Norman M. (2005). Essentials of Entrepreneurship and Small Business Management, $4 \mathrm{rd}$ Edition. New Jersey: Pearson Education, Inc. 